\title{
Smokeless tobacco (paan and gutkha) consumption, prevalence, and contribution to oral cancer
}

\author{
Kamal Niaz ${ }^{1,2,3}$, Faheem Maqbool ${ }^{1,2,3}$, Fazlullah Khan ${ }^{1,2,3}$, Haji Bahadar ${ }^{4}$, Fatima Ismail Hassan ${ }^{1,2,3}$, \\ Mohammad Abdollahi ${ }^{1,2,3}$ \\ 'International Campus, Tehran University of Medical Sciences (IC-TUMS), Tehran, Iran; ${ }^{2}$ Department of Toxicology and Pharmacology, Faculty \\ of Pharmacy, Tehran University of Medical Sciences, Tehran, Iran; ${ }^{3}$ Toxicology and Diseases Group, Pharmaceutical Sciences Research Center, \\ Tehran University of Medical Sciences, Tehran, Iran; ${ }^{4}$ Institute of Paramedical Sciences, Khyber Medical University, Peshawar, Pakistan
}

\begin{abstract}
Smokeless tobacco consumption, which is widespread throughout the world, leads to oral submucous fibrosis (OSMF), which is a long-lasting and devastating condition of the oral cavity with the potential for malignancy. In this review, we mainly focus on the consumption of smokeless tobacco, such as paan and gutkha, and the role of these substances in the induction of OSMF and ultimately oral cancer. The list of articles to be examined was established using citation discovery tools provided by PubMed, Scopus, and Google Scholar. The continuous chewing of paan and swallowing of gutkha trigger progressive fibrosis in submucosal tissue. Generally, OSMF occurs due to multiple risk factors, especially smokeless tobacco and its components, such as betel quid, areca nuts, and slaked lime, which are used in paan and gutkha. The incidence of oral cancer is higher in women than in men in South Asian countries. Human oral epithelium cells experience carcinogenic and genotoxic effects from the slaked lime present in the betel quid, with or without areca nut. Products such as 3-(methylnitrosamino)-proprionitrile, nitrosamines, and nicotine initiate the production of reactive oxygen species in smokeless tobacco, eventually leading to fibroblast, DNA, and RNA damage with carcinogenic effects in the mouth of tobacco consumers. The metabolic activation of nitrosamine in tobacco by cytochrome P450 enzymes may lead to the formation of $\mathrm{N}$-nitrosonornicotine, a major carcinogen, and micronuclei, which are an indicator of genotoxicity. These effects lead to further DNA damage and, eventually, oral cancer.
\end{abstract}

KEY WORDS: Fibrosis, Oral cancer, Areca, Smokeless tobacco, Prevalence

\section{INTRODUCTION}

The term "smokeless tobacco" refers to the consumption of unburned tobacco, in the form of chewing, spitting, dipping, and snuff. Consumers chew the tobacco in the mouth and spit out the juice that builds up. Nicotine and other constituents are absorbed in the lining of oral cavity. People of many regions, including In-

\section{Correspondence: Mohammad Abdollahi}

Faculty of Pharmacy and Pharmaceutical Sciences Research Center, Tehran University of Medical Sciences, Tehran 1417614411, Iran

E-mail:mohammad@tums.ac.ir

Received: Dec 16, 2016 / Accepted: Mar 9, 2017 / Published: Mar 9, 2017

This article is available from: http://e-epih.org/

(C) This is an open-access article distributed under the terms of the Creative Commons Attribution License (http://creativecommons.org/licenses/by/4.0/) which permits unrestricted use, distribution, and reproduction in any medium, provided the original work is properly cited.

(C) 2017, Korean Society of Epidemiology dia, Pakistan, other Asian countries, and North America, have a long history of smokeless tobacco use. Approximately 28 chemical constituents present in smokeless tobacco are carcinogenic in nature, among which nitrosamine is the most prominent [1].

People mostly use paan and gutkha due to a lack of awareness and education. They are not aware of the harmful effects associated with the use of these substances, and it has been reported that these products are consumed for perceived beneficial effects, such as mouth freshening, aid in digestion, germ-killing, astringency, mood enhancement, tension relief, and oral cleaning [1]. Gutkha is sweet in taste, and children consider it to be a form of candy. Many people believe that gutkha is a mouth freshener, but its pleasant taste and sweetness aggregate microbes, causing damage to teeth. The use of paan and gutkha is difficult to control in most countries where it is widespread, and their extensive use leads to oral cancer [2]. The consumption of smokeless tobacco and areca nut is high in South Asian countries in the form of paan. In various South Asian languages, paan simply means "leaf." Various in- 
Table 1. Some common forms of oral smokeless tobacco and their constituents

\begin{tabular}{|c|c|c|}
\hline Common/native name & Ingredients & Countries/populations \\
\hline Toombak & Sodium carbonate and tobacco & Sudan \\
\hline Shammah & Tobacco, slaked lime, and ash & Saudi Arabia \\
\hline Naswar & Tobacco, slaked lime, indigo, cardamom, oil, and menthol & Iran, Afghanistan, Pakistan, Central Asia \\
\hline Nass & Tobacco, ash, cotton, and sesame oil & Iran, Afghanistan, Pakistan, Central Asia \\
\hline Mawa & Areca nut, lime, and tobacco & India \\
\hline Gadakhu & Tobacco and molasses & Central India \\
\hline Zarda & Boiled tobacco & India and Arab countries \\
\hline Paan/betel quid & $\begin{array}{l}\text { Areca nut, betel leaf, slaked lime, spice, and catechu, } \\
\text { with or without tobacco }\end{array}$ & $\begin{array}{l}\text { Indian subcontinent, New Guinea, Southeast Asia, and } \\
\text { South America }\end{array}$ \\
\hline Mishri & Burned tobacco & India \\
\hline
\end{tabular}

gredients are wrapped in the betel leaf. The common components of paan are tobacco, seeds, quenched lime, spices, and areca nut enfolded in betel quid [2]. In many developed and developing countries, tobacco is widely used with other constituents, as shown in Table 1. Over three decades ago, a tobacco industry emerged in India producing gutkha, which consists of slaked lime, areca nut, chewing tobacco, spices, and catechu packed in tins or pouches [2].

Oral submucous fibrosis (OSMF) is a persistent disorder of the oral cavity characterized by irritation and progressive fibrosis of the superficial and deep connective tissues. Oral cancer has been commonly observed in India, Pakistan, Sri Lanka, Taiwan, China, Indonesia, and Malaysia [3,4]. It is believed that the pathogenesis of OSMF is multifactorial, and is associated with nutritional deficiencies; the consumption of smokeless areca nuts, chilies, and lime; genetic abnormalities; betel quid; tobacco smoking; herpes simplex virus; human papilloma virus (HPV); chronic candidiasis; and immunological depression [5]. Oral cancer is the sixth most predominant type of cancer worldwide, affecting both genders equally, although it is particularly common in men in developing countries [6].

Smokeless tobacco and areca nut consumption in various forms is part of traditional culture in the US and in South Asian countries. Essentially, areca nut is the fruit derived from Areca catechu. It is produced in a chewable form and is also the main component of various products used daily by the younger population. Areca nut contains tannins (11 to $26 \%$ ), which act as stimulants, and alkaloids $(0.15$ to $0.67 \%)$, mainly arecoline [2].

Areca nuts are extensively used, and have noxious and stimulant effects. Studies have reported that areca nut leads to diminished hunger, enhanced digestion, altered concentration, and relaxation, and sometimes also increases alertness [2]. The use of gutkha has been shown to have genotoxic and clastogenic properties [1]. In some cases, alcohol plays an important role in oral cancer, rather than smoking [7]. The use of smokeless tobacco products together with alcoholism and smoking increases the chance of oral cancer. In this study, our main focus was on the consumption of paan and gutkha, which are common smokeless products, and their role in the induction of OSMF, which ultimately leads to oral cancer.

\section{METHODS}

A bibliographic search for the current review was conducted on PubMed, Scopus, and Google Scholar for articles on oral cancer due to paan and gutkha consumption. First, a PubMed search was conducted for the following terms: "presence of smokeless tobacco in Taiwan," "prevalence in India," "prevalence in Pakistan," "presence of smokeless in Asia," "occurrence of paan and gutkha in Tanzania," "epidemiological prevalence and presence of smokeless tobacco in Indonesia and Malaysia," "prevalence and presence of paan and gutkha in Cambodia," and "prevalence of paan and gutkha in migrated peoples."

Scopus was searched for terms including: "oral cancer due to paan and gutkha," "genotoxic effect of paan," "paan and gutkha chewers," "betel quid compounds," "risk factor of oral cancer," "prevalence of oral cancer," "paan associated with oral cancer," "smokeless products lead to oral cancer," and "gutkha usage." Google Scholar was searched for keywords such as "carcinogenic effect of betel," "mechanism of oral cancer due to paan and gutkha", "ban of paan and gutkha," and "OSMF mechanism and etiopathogenesis." The data included in this article were filtered to ensure that they were specifically related to human beings and some laboratory animals. Most studies that investigated the toxicity of tobacco in other systems were excluded. Furthermore, articles were excluded if the data on oral cancer were associated with other brain and neck cancers. Studies that focused on single or limited cases with adverse effects but did not show a clear role of smokeless tobacco in the pathogenesis were also excluded. Eventually, a total of 90 reports indexed in Google Scholar and/or PubMed were found to satisfy the inclusion criteria. Studies not indexed in PubMed were obtained by manual searching in Google Scholar, and 10 such reports that satisfied the inclusion criteria were additionally retrieved. Therefore, a total of 100 studies were included in this review (Figure 1). 

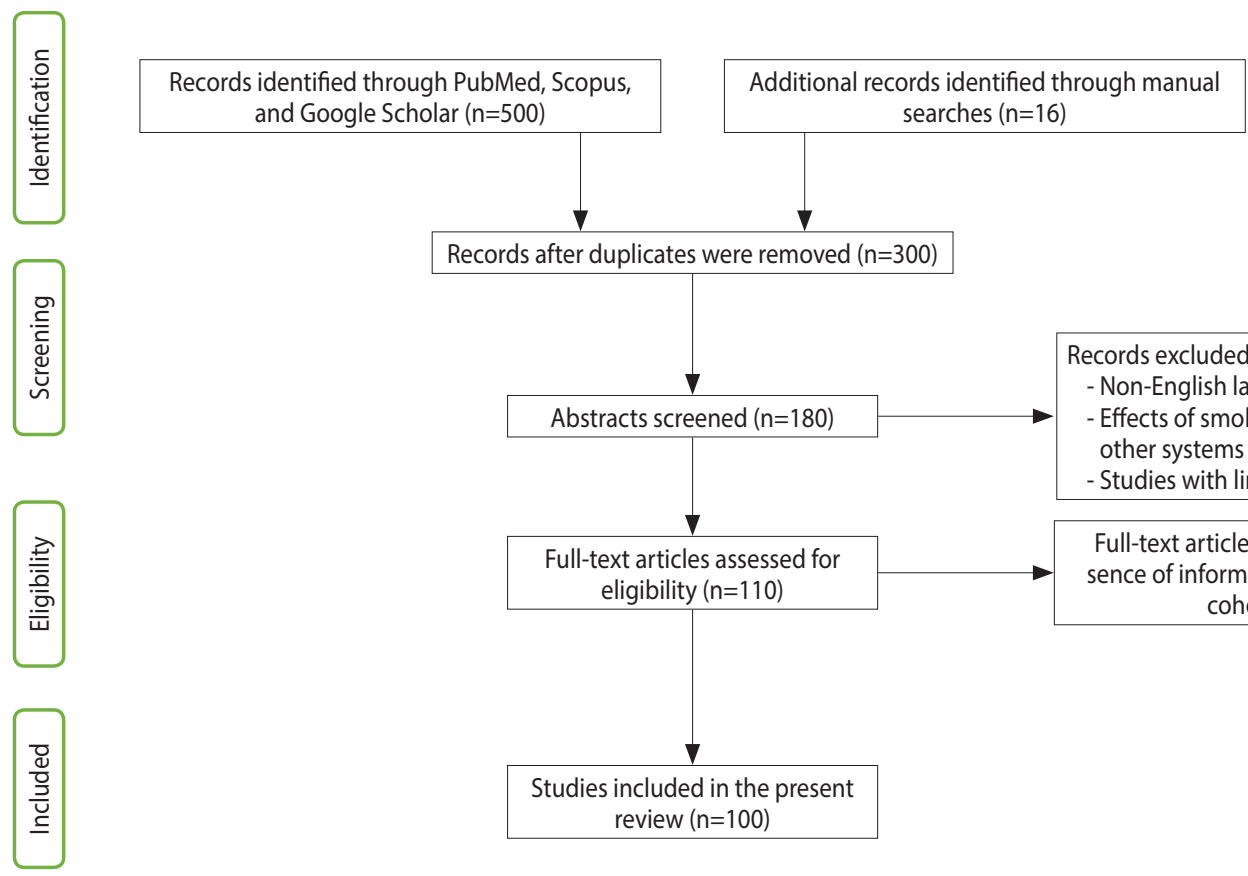

]

Records after duplicates were removed $(n=300)$

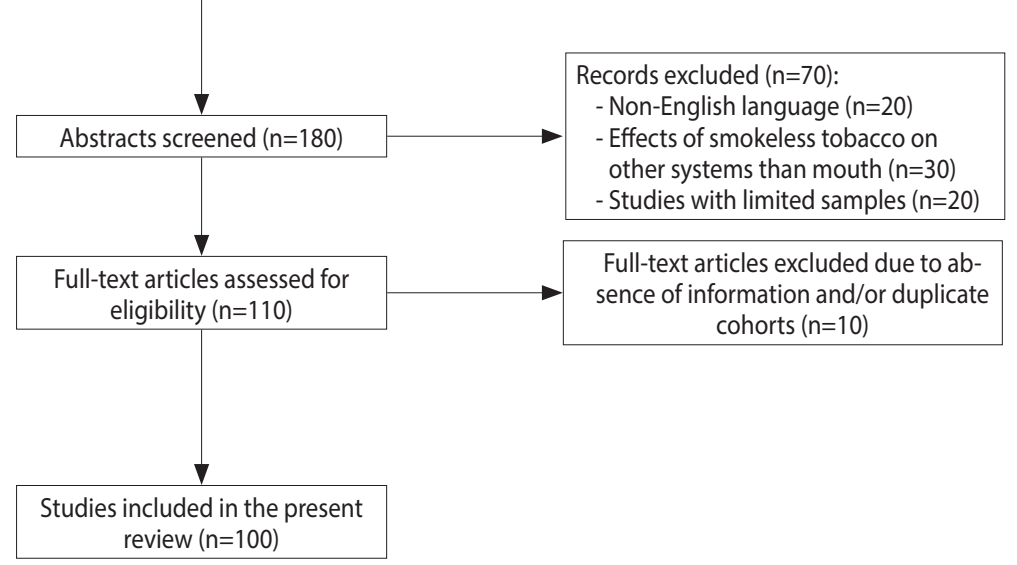

Figure 1. Flow diagram of the included studies. The flow chart presents the number of citations and resources that were screened, excluded, and/or included in the review.

\section{GEOGRAPHIC PREVALENCE OF USAGE OF SMOKELESS TOBACCO PRODUCTS AND ORAL CANCER}

The habit of chewing areca nut in various products has been reported in many countries, such as Thailand, Sri Lanka, Bangladesh, Pakistan, Malaysia, Cambodia, China, Indonesia and New Guiana. In addition, it is also widespread in the migrant populations in places such as the UK, South and East Africa, Australia, and North America [4]. In New Guiana, people use betel quid separately, with lime kept in the commissure of the mouth [8]. In Southeast Asian countries, tobacco is often used with betel quid, and smoking is also common. Inhabitants of the mountains of Cambodia, Myanmar, Thailand, and Laos add areca to the roots of other local plants, such as cinnamon and cloves, in the betel quid for consumption [9]. Approximately 390,000 cases of oral and/or pharyngeal cancers occur annually worldwide, of which around $58 \%$ are in South and Southeast Asian countries [2]. Some countries in which smokeless tobacco is consumed are discussed below.

\section{Taiwan}

Traditionally, tobacco has been consumed as part of the culture in some countries of the world. However, in Taiwan, an increase in the consumption of paan, gutkha and other smokeless tobacco products has been reported, especially among children and teenagers. Many epidemiological studies have been conducted in Taiwan, where betel leaves or betel inflorescence is used with areca nut. The prevalence of smokeless tobacco use among men and women is 9.8 and 1.6\%, respectively [10]. In 1991, a survey-based study was conducted among the residents of Kaohsiung in Taiwan; among 1,162 individuals aged 15 years and above, 13.3\% consumed betel quid and $2.8 \%$ were daily chewers [11]. The increase in the usage of betel quid has been investigated in many studies. The phenomenon appears due to the surplus in markets and shops selling ready-made quid. In more than $53 \%$ of cases, use of these products started among family members influenced by the grandfather and father [10]. In another school-based survey in Taiwan, the consumption of betel quid was higher, especially among boys rather than girls. It was also common amongst those who used to drink alcohol or smoke tobacco [10,12]. Betel quid use was common in professional schools rather than senior or junior high-school $[12,13]$.

\section{India}

According to the National Report of Global Adult Tobacco Survey conducted in India and Bangladesh, the current prevalence of smokeless tobacco use is 25.9 and $27.2 \%$, respectively. There are 30 different types of smokeless products available in these countries, including zarda, which contains dried and boiled tobacco leaves, limes, areca nut, additives, spices, and tannins [14]. Oral cancer accounts for 30 to $40 \%$ of cancer cases reported in India, and the most obvious cause is the extensive use of tobacco products, consumed via smoking and/or smokeless chewing products [15]. In addition, oral cancer occurrence is especially high in Uttar Pradesh in north India due to the extraordinary rate of consumption of smokeless tobacco products, such as paan and gutkha [16].

In India, the prevalence of oral cancer is high. It has been previously documented that besides other factors, the extensive use of 
paan, gutkha, and zarda could also contribute to the development of oral cancer [2]. In India, mostly children and teenagers chew gutkha occasionally or regularly. In Mumbai, $40 \%$ of school students and $70 \%$ of college students have been reported to regularly consume gutkha. Although some states of India have banned gut$k$ ha consumption due to its carcinogenic properties and other hazardous effects, it is still actively sold on the black market [2]. In addition, the widespread habit of paan and gutkha use is not limited to the Indian subcontinent, but extends to immigrants living in US and Europe [17-20]. In the Indian city of Wardha, gutkha was found to be used by approximately $46.4 \%$ of men and $20 \%$ of women [18].

\section{Pakistan}

After India, Pakistan is the second prominent country in which these smokeless tobacco products are consumed, with a prevalence among Pakistani men and women of 21.3 and $19.3 \%$, respectively. More than $90 \%$ of oral cancer cases have been reported to be associated with the use of tobacco products, indicating that they are vital factors triggering oral cancer. A study reported that women who chewed tobacco more than 10 times a day had a higher risk of oral cancer than non-tobacco chewers [21]. A study conducted by Muwonge et al. [22] reported that smokeless tobacco users were at a higher risk of oral cancer, along with other abnormalities, than tobacco smokers.

Worldwide, almost 600 million people consume areca nut as part of traditions and/or everyday life. Many epidemiological studies in India and Pakistan have reported that 3.3 to $37.0 \%$ of people chewed paan. In Pakistan and India, oral cancer is the most common type of cancer, after breast and lung cancer. Breast cancer is mostly observed among women [23]. The incidence of mouth, tongue, hypopharynx, nasopharynx, and lip cancer was found to be equal between men and women in Karachi, Pakistan [16,24-26].

The use of these products is considered to be a normal cultural practice. Paan, gutkha, chaalia, naswar, and toombak are widely used, but ultimately lead to OSMF and oral cancer. Various studies have suggested that in Pakistan, India, and Nepal, 20 to $30 \%$ of adults and teenagers use these products [27-29]. In Karachi, Pakistan, $40 \%$ of the populations have used chewable betel, areca, and tobacco products in their daily life [30]. The overall prevalence of the use of the above products in men and women was 50.3 and $28.5 \%$, respectively. A study conducted among school children in Karachi, Pakistan, reported that more than $74 \%$ of students used chewable products on a daily basis [31]. According to a report in 2006, the general use of paan, chaalia, gutkha, naswar, and toombak was determined to be $34.3,34.7,46.0$, and $50.0 \%$ in the Sindh, Punjab, Pathan, and Mohajir provinces, respectively [19].

The prevalence of paan and gutkha has been reliably documented, although fluctuating results have been reported in investigations of specific communities. A study conducted one decade previously found that $46 \%$ of the residents of Karachi, Pakistan consumed gutkha habitually [32]. Similarly, in another study it was found that $35 \%$ of the patients visiting a health care center in Karachi, Pakistan, were habitual consumers of paan, gutkha, and/or other smokeless tobacco products [17].

Table 2. Summary of the risk factors for oral cancer in various Asian countries

\begin{tabular}{|c|c|c|c|c|}
\hline Country & Associated risk factors & Study design & No. of subjects & Reference \\
\hline Taiwan & $\begin{array}{l}\text { Quid without tobacco, smoking, alcohol, } \\
\text { heavy metals, HPV, SEC }\end{array}$ & Questionnaire-based & 4,906 & {$[12]$} \\
\hline Vietnam & Quid with tobacco & $\begin{array}{l}\text { Visitors to cancer centers and institute of odontology, } \\
\text { relevant publications in Vietnamese, interviews with } \\
\text { betel quid vendors and individual betel quid users }\end{array}$ & - & [33] \\
\hline Pakistan & $\begin{array}{l}\text { Paan, gutkha, SEC, smokeless tobacco, bidi } \\
\text { and cigarette smoking }\end{array}$ & Structured questionnaires & 425 & {$[19]$} \\
\hline Sri Lanka & Betel quid, tobacco & Cross-sectional community-based study & 1,029 & [34] \\
\hline Yemen & $\begin{array}{l}\text { Cigarette smoking, smokeless tobacco, quid } \\
\text { with tobacco }\end{array}$ & History-based study & 649 & {$[35]$} \\
\hline India & $\begin{array}{l}\text { Quid with or without tobacco, smokeless } \\
\text { tobacco, alcohol, bidi and cigarette } \\
\text { smoking, HPV, diet, SEC }\end{array}$ & Nested case-control design & 1,692 & {$[22]$} \\
\hline Philippines & Quid, smoking & Case-control study & 566 & {$[36]$} \\
\hline Thailand & $\begin{array}{l}\text { Family history of cancer, alcohol, smoking, } \\
\text { quid with tobacco }\end{array}$ & Case-control study & 104 & [37] \\
\hline Malaysia & Malnutrition, HPV & Research analysis of frozen samples of oral tissue & 210 & {$[38]$} \\
\hline Nepal & Bidi & Epidemiological study & $\begin{array}{l}\text { Population aged } \\
\text { more than } 15 \mathrm{yr}\end{array}$ & [39] \\
\hline Turkey & Malnutrition, alcohol, cigarette smoking, SEC & Case-control study & 140 & [40] \\
\hline
\end{tabular}

HPV, human papillomavirus; SEC, socioeconomic conditions. 


\section{Tanzania}

In Tanzania, 7\% of the native inhabitants were found to use gut$k h a$ on a daily basis [41]. In addition to paan and gutkha, other risk factors were found to be involved in the development of oral cancer, as shown in Table $2[21,42,43]$.

\section{Cambodia}

In Cambodia, most users add tobacco to quid, and another practice is to rub it into the gum after chewing betel quid. The consumers of smokeless tobacco were mostly elder women [44]. In an epidemiological study, it was reported that $32.6 \%$ of women and $0.8 \%$ of men above 15 years of age chewed betel quid. Most of the men were approximately 50 years of age, and most of the women chewers were over the age of 39 in that study. Overall, smoking was prevalent in men (43\%), but rare in women (4.5\%) [45].

In the Pacific island of Palau, areca nut is chewed in a green unripe state, with other spices and flavoring ingredients. A population-based study conducted in 1991 revealed that $80 \%$ of women and $70 \%$ of men chewed areca nut or betel quid, $80 \%$ of whom included tobacco in the betel quid [46].

\section{Indonesia and Malaysia}

The use of smokeless tobacco is different in these countries. In Indonesia, first the betel quid is chewed, and finally a fine-cut tobacco is used to clean the teeth, while keeping it in the mouth for a moment [8]. In Malaysia, use of paan and gutkha is high among some native groups, who use betel quid with tobacco.

\section{Usage in migrant communities}

The high risk of oral cancer among migrants in the UK is due to the massive consumption of betel quid and other smokeless products. People who have migrated from Pakistan, India, Bangladesh, and Sri Lanka to the UK are the major communities in which betel quid use is widespread [47]. Various studies have found that over $80 \%$ of adults from Bangladesh in London used betel quid and other products, with no gender differences. The use of tobacco, in smoking or in smokeless forms, is common among men and women [48,49]. The usage of these products is becoming well known in these communities. Studies conducted on betel quid and tobacco use among South Asian emigrants to Western countries have pointed out the lack of awareness of oral cancer risk regardless of gender, age, national group, and social class. Individuals tend to be more aware of smoking, but not attentive to other habits that pose a risk of oral cancer, such as paan and gutkha.

\section{MECHANISM OF GENOTOXICITY AND CARCINOGENICITY}

Paan, gutkha, and zarda are taken by mouth, chewed, sucked, or applied to the teeth and gums. The World Health Organization has classified smokeless tobacco products as human carcinogenic compounds, in particular tobacco-specific nitrosamines, which account for 76 to $91 \%$ of the total N-nitroso compound (NOC) burden [14]. These products have been associated with oral and pancreatic cancers, cardiovascular disease, periodontal disease, asthma, and deformities in the women reproductive system [1]. The mechanisms of paan and gutkha that have been proposed for humans are summarized in Figure 2 [42,43]. Studies have shown that tobacco users who include slaked lime in betel quid or with areca nut experience carcinogenic and genotoxic effects in human oral epithelium cells. These products generate reactive oxygen species (ROS) in the oral cavity of chewers [50]. A study conducted in India reported that the greatest extent of DNA disruption was observed in gutkha consumers who smoked, with the following order of the extent of DNA denaturation: gutkha+smoking $>$ paan + smoking $>$ gutkha only $>$ paan only $>$ smoking only $>$ no tobacco use [51].

The different ingredients used in paan and gutkha have their own detrimental effects, such as catechu, which consists of tannin and polyphenols, which have a high tendency to cause esophageal cancer and are characterized by mutagenicity and clastogenicity [52-54]. The lime (calcium hydroxide) used can result in an alkaline $\mathrm{pH}$, triggering $\mathrm{ROS}$ release and causing irritation of the oral mucosa and hyperplasia [55]. Areca nut consists of phenolic compounds, and tobacco releases various nitrosamines in the mouth that are responsible for proliferative abrasions and damage to DNA and fibroblasts $[42,56]$.

A Mexican study conducted in 2006 indicated that single-cell gel electrophoresis is a safe method of determining DNA damage in human populations [57]. When the amount of ROS production in cells is increased in the presence of a normal detoxification system, oxidative stress leads to cellular damage, along with DNA damage [58]. DNA destruction may occur in the form of doublestrand or single-strand DNA breaks [59]. Areca nut is the main component of paan and gutkha, while the areca nut used in gut-

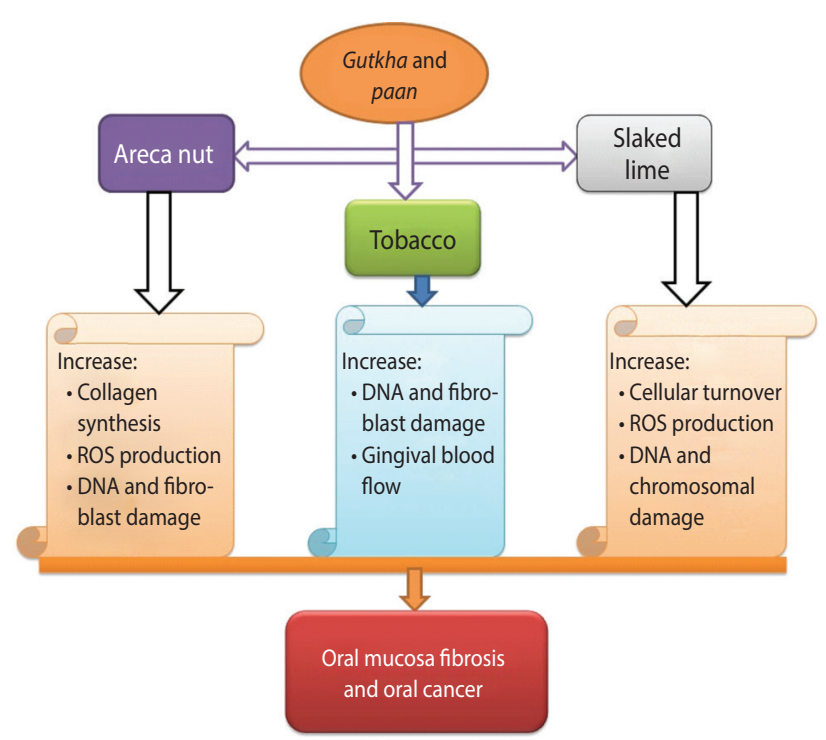

Figure 2. Roles of paan and gutkha in oral submucous fibrosis [42,43]. ROS, reactive oxygen species. 
kha leads to OSMF [60]. The incidence of micronuclei (MN) was observed among OSMF patients who chewed gutkha [51]. Studies have shown that ROS production triggered OSMF [61]. NOCs extracted from areca nuts, which contain the active substance 3(methylnitrosamino)proprionitrile, have been found to cause genotoxicity and cytotoxicity responsible for tumors in the buccal cavity of smokeless tobacco consumers [62]. The long-lasting and frequent presence of paan and gutkha in the mouth around the gums leads to inflammation of the oral mucosa, which causes the activation of T-cells and macrophages, and ultimately the release of prostaglandins (PGs). PG production occurs in keratinocytes of the buccal cavity due to areca nut extract, and this plays a significant role in oral tissue fibrosis and cancer. Cytokines such as interferon- $\alpha$, tumor necrosis factor (TNF), interleukin- 6 , and growth factor-like transforming growth factor-beta have been found to be produced at the sites of irritation [63]. These chemical substances make important contributions to OSMF and premalignancy (Figure 3) $[53,63]$.

Genotoxic effects occur from paan and gutkha mostly due to the presence of nitrosamine, as shown in Table 3. The nitrosamine in the chewers' saliva undergoes nitration during betel quid chewing when it reacts with nitrite in the presence of a catalyst $[42,64]$. The nitrosamine in tobacco undergoes metabolic activation by cytochrome P450 enzymes, which may lead to the formation of $\mathrm{N}$-nitrosonornicotine, a major carcinogen [65], which further leads to DNA damage and ultimately oral cancer. $\mathrm{MN}$ are small chromatin bodies that appear during cell division in the cytoplasm due to the condensation of whole chromosomes or acrocentric chromosomes; this is the only biomarker used to identify genotoxicity during sister chromatid exchange and chromosomal aberrations

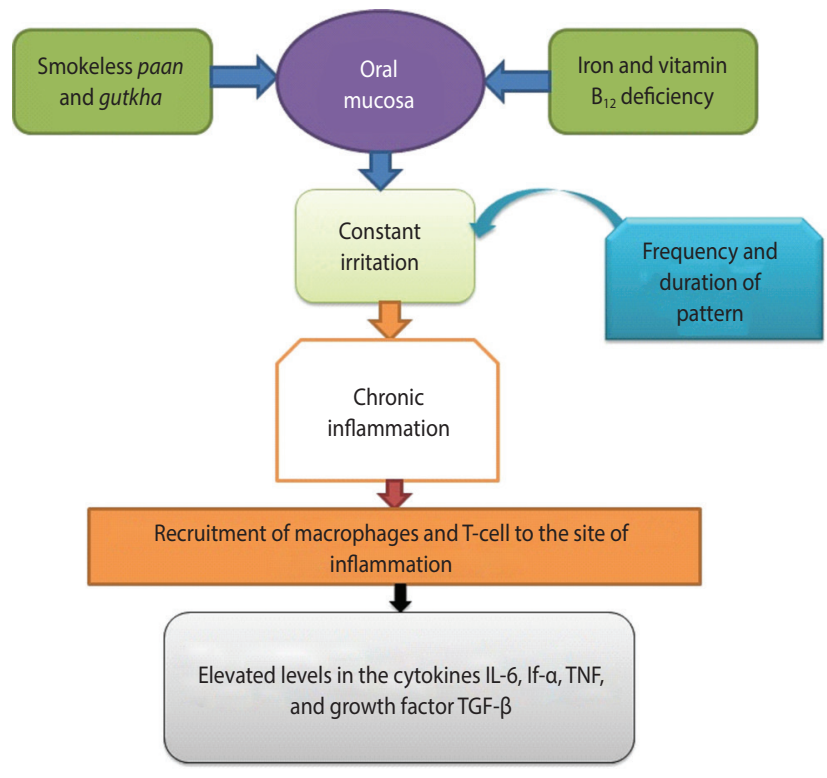

Figure 3. Initial events in the pathogenesis of mouth cancer [56,63]. IL-6, interleukin-6; If-a, interferon-alpha; TNF, tumor necrosis factor; TGF- $\beta$, transforming growth factor-beta.
[66]. Multiple genes are involved in the breakdown of carcinogens, and the most frequently observed evidence has suggested that cytochrome polymorphisms (CYPs) affect the risk of oral cancer. Arecaidine, arecoline, and other similar ingredients of betel quid exist in minute quantities in human blood, and arecoline levels have been associated with the use of betel quid [67]. We have summarized the effects of CYPs, which are connected with the chewing of betel quid and lead to cancer of the oral cavity and pharynx,

Table 3. Studies of the genotoxicity of paan and gutkha

\begin{tabular}{|c|c|c|}
\hline Study & Source & Endpoints \\
\hline Paan/gutkha [67] & $\mathrm{BC}$ & MN \\
\hline Tobacco [68] & EOMC & MN \\
\hline Betel quid, areca, and tobacco [69] & $\mathrm{BC}$ and $\mathrm{PBL}$ & CA and $\mathrm{MN}$ \\
\hline Tobacco [70] & $\mathrm{EBC}$ and $\mathrm{PBL}$ & - MN and CA \\
\hline Paan [71] & CC & $\mathrm{CA}, \mathrm{SCE}$, and $\mathrm{MN}$ \\
\hline Paan/betel quid [72] & TRP & QBT \\
\hline Lime [73] & EOMC & $\mathrm{CT}$ and $\mathrm{MN}$ \\
\hline Slaked lime [74] & PMB & $\mathrm{HE}$ \\
\hline Areca nut [75] & STS & Mutagenicity \\
\hline Areca nut [76] & HBEC & CFFA, NRA, TRA \\
\hline Paan [77] & Ovary cells & SCE and CA \\
\hline Tobacco products [78] & ME, CTLE & Ames assay \\
\hline Catechu [79] & Liver tissue & Ames assay \\
\hline Arecoline [80] & BMC & SCE \\
\hline Paan [81] & Mice & SCE \\
\hline Paan [82] & PBL & $\mathrm{SCE}, \mathrm{CA}$, and $\mathrm{MN}$ \\
\hline Paan, tobacco [83] & $\mathrm{HOK}$ & NHOKs \\
\hline Paan [84] & BPL & $\mathrm{MN}, \mathrm{CA}$, and SCE \\
\hline Tobacco [85] & VTF & DTT \\
\hline Paan [86] & Mice & MA \\
\hline Betel quid/paan [72] & TRP & QBT \\
\hline Tobacco [87] & SNT & DTT \\
\hline Gutkha/paan [88] & $\mathrm{BMC}$ & $\mathrm{MN}$ \\
\hline Tobacco, areca nuts, and betel leaf [69] & $\mathrm{PBL}$ and $\mathrm{BC}$ & $\mathrm{MN}$ and $\mathrm{CA}$ \\
\hline Tobacco [70] & PBL and EBC & CA and $M N$ \\
\hline Paan [89] & Rats & MEA \\
\hline
\end{tabular}

SCE, sister chromatid exchange; CA, chromosomal aberrations; STS, Salmonella typhimurium strains; PMB, popular band of paan; TRP, tobacco and its related products; $\mathrm{CC}$, cultured cells; EBC, exfoliated buccal mucosal cells; PBL, peripheral blood lymphocytes; BC, buccal cells; MN, micronuclei; QBT, questionnaire about betel quid type; $\mathrm{HBEC}$, human buccal epithelial cells; BMC, bone marrow cells; EOMC, exfoliated oral mucosal cells; ME, extract of masher; HOK, human oral keratinocytes; SNT, smoking and non-smoking forms of tobacco; CTLE, chewing tobacco and lime; MA, morphological abnormalities; NHOKs, normal human oral keratinocytes; $\mathrm{CT}$, chemiluminescence technique; $\mathrm{HE}$, histological examination; CFFA, colony-forming efficiency assay; VTF, various tobacco forms; NRA, neutral red uptake assay; TRA, trypan blue exclusion assay; MEA, marker of enzyme activities. 


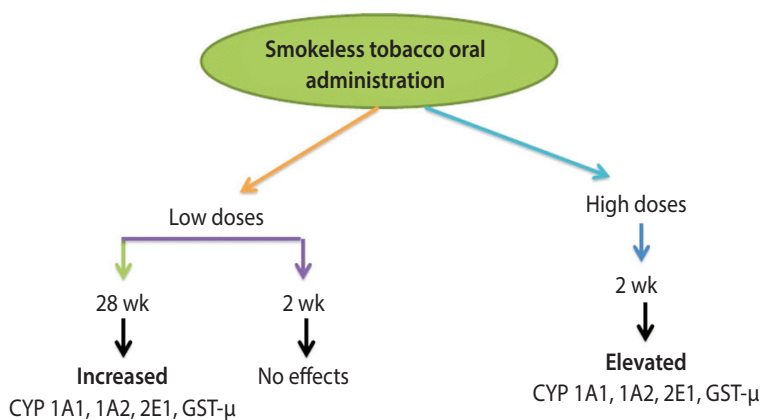

Increased: Micronuclei formation, TNF- $a$, Myeloperoxidase, Bax, P53, TN-KB, and TN-KB

Figure 4. Molecular mechanism of gutkha $[90,91]$. CYP, cytochrome polymorphism; GST- $\mu$, $\mu$-glutathione-s-transferase; TNF, tumor necrosis factor.

in Figure 4 [90,91]. Among the CYPs, CYP1A1 and CYP2E1 may trigger nitrosamines, which ultimately affect the mouth, potentially leading to malignant disorders [91]. In particular, $\mu$-glutathione-stransferase was found to enhance TNF- $\alpha$. Meanwhile, MN have been used for decades as a biomarker of genotoxic effects. The prolonged use of chewing or masticatory products such as supari, paan, and gutkha can lead to the development of different types of oral cancer. It is therefore necessary to evaluate the population at high risk due to using these products at high doses on a daily basis. Paan and gutkha have been found to have carcinogenic effects in laboratory animals, causing tumors in various organs, such as the liver, mouth, pharynx, and larynx. Paan acts as a cancer-promoting agent in mice [92]. A study was conducted in which mice that were fed with paan or gutkha exhibited tumors in the testes, ovary, liver, kidney, stomach, and lung. This suggests that gutkha and paan are not only carcinogenic for the oral cavity, but may also exert deleterious effects on other organs [93].

\section{DISCUSSION}

Studies have shown that paan and gutkha comprise trace elements, such as magnesium, chlorine, calcium, sodium, manganese, copper, bromine, and vanadium. The copper content in these two products is more than other nuts consumed. The average content of copper in these processed products existing in betel nuts was $18 \pm 9 \mu \mathrm{g} / \mathrm{g}$, which is sufficient to exert deleterious effects on human health. According to the Indian Food Report, this concentration was 2.5 times greater than in raw betel nuts. The cellular metabolism of betel nuts and quid leads to the production of ROS, such as hydrogen peroxide and superoxide anion radicals, at a $\mathrm{pH}$ of more than 9.5 [43]. Saliva has the potential to inhibit the production of these ROS and other free radicals from the constituents of betel quid. Nonetheless, hydrogen peroxide and oxygen production occurs due to the alkaline $\mathrm{pH}$ that arises from the addition of slaked lime when chewing these products [73,94].

It seems that there is an association between oral inflammatory conditions and the age of individuals who use smokeless tobacco products [95]. However, paan and gutkha may also expose the consumers to other oral mucosal disorders at any stage of life. Javed et al. [32] reported that gutkha chewers 45-65 years of age had more periodontal inflammation. A study that investigated the effects of smokeless tobacco on blood flow response showed that tobacco significantly increased gingival blood flow, arterial blood pressure, and heart rate [96]. In addition, paan and gutkha chewers also have been found to exhibit reduced salivation and mucus formation, thereby reducing the normal microflora of the oral cavity and exposing the mouth to pathogens such as Aspergillus species [97]. For this reason, reduced salivation may also permit pathogens to accumulate in the supragingival and subgingival areas, thus increasing periodontal inflammation in gutkha chewers compared to non-chewers [98].

OSMF was an infrequent disease/condition during the 1960s and 1970s, with a prevalence in older individuals of approximately $0.1-0.5 \%$. Subsequently, in the Indian subcontinent, the consumption of areca nut mixtures in products such as paan and gut$k h a$ has led to an epidemic of OSMF in adolescents [99,100]. Casecontrol studies in New Delhi, Maharashtra, Gujarat, Nagpur, and Bhavnagar have reported that more than $70 \%$ of cases of OSMF occurred in people under 35 years of age $[2,69,99,100]$. Paan and gutkha chewers develop this condition more frequently than betel quid chewers. The incidence of OSMF is $75 \%$ after 4.5 and 9.5 years of use of paan and betel quid, respectively. The lack of betel quid leaf in paan and the higher levels of areca nuts may facilitate the development of OSMF in paan and gutkha users [21].

Areca nuts mixed with tobacco are not an etiological agent contributing to the development of submucous fibrosis. However, it is thought that the high occurrence of OSMF is due to its effect of enhancing addiction, leading to greater exposure to areca nut chewing. In a range of studies, OSMF was recognized as an extremely hazardous precancerous state. In a cohort study, 12,212 tobacco consumers with OSMF were at a higher risk of malignant transformation than tobacco users without any precancerous lesions $[61,69,99]$. Sufficient evidence has emerged that betel quid with tobacco, tobacco consumed by chewing with lime, betel quid with or without tobacco, and areca nuts are human carcinogens $[69,73]$. The use of these products has reached such a proportion that the government has no choice but to ban these products. In public health, banning such extensively used products is difficult and not ideal. In particular, betel quid should be banned, as paan and gut$k h a$ are items containing betel quid. The Central Committee of Food Safety of India has issued letters to the central government in support of a ban of betel quid, areca nut, paan, and gutkha.

The reasons for which the Central Committee of Food Safety consistently wants to ban the manufacturing and marketing of these products include: 1) adolescents and teenagers are becoming more addicted; 2) consumers develop OSMF, a precancerous condition, and cancer more quickly than smokers; and 3) women prefer smokeless tobacco due to the social disapproval of smoking and thereby become addicted to gutkha. Thus, in India, all legal 
evaluation processes necessary to ban gutkha nationally have been accomplished, but it continues to be manufactured and marketed in the black market and/or legally.

In the following states of India, gutkha and paan have been banned: Andhra Pradesh, Goa, Maharashtra (August 1, 2002), and Tamil Nadu (November 19, 2001). Certainly, gutkha producers are on the defensive [20]. Gutkha and paan producers have stated that these regulations were not catastrophic, as these products remain legal in the UK and Singapore, according to the Times of India. Thus, they continue to export paan and gutkha to the UK, Singapore [18,20], Middle East, Japan, and Australia, as well as across South Asia.

\section{CONCLUSION}

In the present study, it was concluded that the extensive use of smokeless tobacco in different forms leads to OSMF, which potentially transforms into a malignant condition in all age groups. The genotoxic and carcinogenic effects of smokeless tobacco in the oral cavity are due to the production of ROS and free radicals. These free radicals and ROS damage the normal DNA and RNA, leading to genotoxicity and, eventually, oral cancer. Previously described mechanisms explain the induction, maintenance, and progression of OSMF due to paan and gutkha. Strict cessation of smokeless tobacco use and follow-up should be implemented to reduce the incidence of oral cancer. Widespread use of these and other products by children, as well as adolescents, is mostly due to their pleasant taste, low cost, and easy availability. Oral cancer rates are increasing due to use of these smokeless tobacco products, in particular among the lower socioeconomic levels that constitute the large majority of the population. It is therefore important to establish appropriate data management, monitoring, and evaluation systems. In addition, oral cancer control policies should be implemented to change the lifestyle and behavior of high-risk populations.

\section{ACKNOWLEDGEMENTS}

The authors wish to thank the Iran National Science Foundation (INSF).

\section{CONFLICT OF INTEREST}

The authors have no conflicts of interest to declare for this study.

\section{ORCID}

Kamal Niaz: $h t t p: / / o r c i d . o r g / 0000-0001-8670-4356$; Faheem Maqbool: $h t t p: / / o r c i d . o r g / 0000-0001-7728-664 X$; Fazlullah Khan: http: //orcid.org/0000-0003-2473-6090; Haji Bahadar: http://orcid.org/ 0000-0003-2458-5843; Fatima Ismail Hassan: http://orcid.org/00000003-1250-0048; Mohammad Abdollahi: http://orcid.org/0000-00030123-1209

\section{REFERENCES}

1. Banerjee SC, Ostroff JS, Bari S, D’Agostino TA, Khera M, Acharya S, et al. Gutka and Tambaku Paan use among South Asian immigrants: a focus group study. J Immigr Minor Health 2014;16:531539.

2. Shah G, Chaturvedi P, Vaishampayan S. Arecanut as an emerging etiology of oral cancers in India. Indian J Med Paediatr Oncol 2012; 33:71-79.

3. Gupta PC, Warnakulasuriya S. Global epidemiology of areca nut usage. Addict Biol 2002;7:77-83.

4. Pillai R, Balaram P, Reddiar KS. Pathogenesis of oral submucous fibrosis. Relationship to risk factors associated with oral cancer. Cancer 1992;69:2011-2020.

5. Johnson N. Tobacco use and oral cancer: a global perspective. J Dent Educ 2001;65:328-339.

6. Changrani J, Gany F. Paan and Gutka in the United States: an emerging threat. J Immigr Health 2005;7:103-108.

7. Thomas G, Hashibe M, Jacob BJ, Ramadas K, Mathew B, Sankaranarayanan $\mathrm{R}$, et al. Risk factors for multiple oral premalignant lesions. Int J Cancer 2003;107:285-291.

8. Pindborg, JJ, Murti PR. Bhonsle RB. Gupta PC. Global aspects of tobacco use and its implications for oral health. In: Gupta PC, Hammer JE, Murti RR, editors. Control of tobacco-related cancers and other disease. Proceedings of an International Symposium; 1990 Jan 15-19; Bombay. Bombay; Oxford University Press; 1992, p. 1323.

9. Awang M. Areca catechu (betel) nut and oral submucous fibrosis [dissertation]. London: University of London; 1983.

10. Lu CT, Lan SJ, Hsieh CC, Yang MJ, Ko YC, Tsai CC, et al. Prevalence and characteristics of areca nut chewers among junior high school students in Changhua county, Taiwan. Community Dent Oral Epidemiol 1993;21:370-373.

11. Chen JW, Shaw JH. A study on betel quid chewing behavior among Kaohsiung residents aged 15 years and above. J Oral Pathol Med 1996;25:140-143.

12. Yang MS, Su IH, Wen JK, Ko YC. Prevalence and related risk factors of betel quid chewing by adolescent students in southern Taiwan. J Oral Pathol Med 1996;25:69-71.

13. Ho CS, Gee MJ, Tsai CC, Lo CI, Wang SC. The prevalence of betel chewing among the students of the different senior high schools in southern Taiwan. Kaohsiung J Med Sci 2000;16:32-38.

14. Tricker AR, Preussmann R. The occurrence of N-nitrosocompounds [corrected] in zarda tobacco. Cancer Lett 1988;42:113118.

15. Ali SM, Qureshi R, Jamal S. Prevalence of oral submucous fibrosis and use of tobacco and related products amongst school going males. Pak Oral Dent J 2011;31:384-387.

16. Mehrotra R, Singh M, Gupta RK, Singh M, Kapoor AK. Trends of prevalence and pathological spectrum of head and neck cancers in North India. Indian J Cancer 2005;42:89-93.

17. Ali NS, Khuwaja AK, Ali T, Hameed R. Smokeless tobacco use among adult patients who visited family practice clinics in Kara- 
chi, Pakistan. J Oral Pathol Med 2009;38:416-421.

18. Dongre A, Deshmukh P, Murali N, Garg B. Tobacco consumption among adolescents in rural Wardha: where and how tobacco control should focus its attention? Indian J Cancer 2008;45:100106.

19. Mazahir S, Malik R, Maqsood M, Merchant KA, Malik F, Majeed A, et al. Socio-demographic correlates of betel, areca and smokeless tobacco use as a high risk behavior for head and neck cancers in a squatter settlement of Karachi, Pakistan. Subst Abuse Treat Prev Policy 2006;1:10.

20. Changrani J, Gany FM, Cruz G, Kerr R, Katz R. Paan and gutka use in the United States: a pilot study in Bangladeshi and IndianGujarati immigrants in New York City. J Immigr Refug Stud 2006; 4:99-110.

21. Krishna Rao SV, Mejia G, Roberts-Thomson K, Logan R. Epidemiology of oral cancer in Asia in the past decade--an update (2000-2012). Asian Pac J Cancer Prev 2013;14:5567-5577.

22. Muwonge R, Ramadas K, Sankila R, Thara S, Thomas G, Vinoda J, et al. Role of tobacco smoking, chewing and alcohol drinking in the risk of oral cancer in Trivandrum, India: a nested case-control design using incident cancer cases. Oral Oncol 2008;44:446-454.

23. Ferlay J, Shin HR, Bray F, Forman D, Mathers C, Parkin DM. Estimates of worldwide burden of cancer in 2008: GLOBOCAN 2008. Int J Cancer 2010;127:2893-2917.

24. Curado MP; International Agency for Research on Cancer (IARC); World Health Organization. Cancer incidence in five continents. Vol. IX. Lyon: IARC; 2007, p. 258.

25. Bhurgri Y, Bhurgri A, Hassan SH, Zaidi SH, Rahim A, Sankaranarayanan R, et al. Cancer incidence in Karachi, Pakistan: first results from Karachi Cancer Registry. Int J Cancer 2000;85:325329.

26. Bhurgri Y. Cancer of the oral cavity - trends in Karachi South (19952002). Asian Pac J Cancer Prev 2005;6:22-26.

27. Gupta PC, Ray CS. Epidemiology of betel quid usage. Ann Acad Med Singapore 2004;33:31-36.

28. Qidwai W, Saleheen D, Saleem S, Andrades M, Azam SI. Are our people health conscious? Results of a patients survey in Karachi, Pakistan. J Ayub Med Coll Abbottabad 2003;15:10-13.

29. Mahmood Z. Smoking and chewing habits of people of Karachi-1981. J Pak Med Assoc 1982;32:34-37.

30. Khawaja MR, Mazahir S, Majeed A, Malik F, Merchant KA, Maqsood M, et al. Knowledge, attitude and practices of a Karachi slum population regarding the role of products of betel, areca and smokeless tobacco in the etiology of head \& neck cancers. J Pak Med Assoc 2005;55:S41.

31. Shah SM, Merchant AT, Luby SP, Chotani RA. Addicted schoolchildren: prevalence and characteristics of areca nut chewers among primary school children in Karachi, Pakistan. J Paediatr Child Health 2002;38:507-510.

32. Javed F, Altamash M, Klinge B, Engström PE. Periodontal conditions and oral symptoms in gutka-chewers with and without type 2 diabetes. Acta Odontol Scand 2008;66:268-273.

33. Reichart PA, Nguyen XH. Betel quid chewing, oral cancer and other oral mucosal diseases in Vietnam: a review. J Oral Pathol Med 2008;37:511-514.

34. Amarasinghe HK, Usgodaarachchi US, Johnson NW, Lalloo R, Warnakulasuriya S. Betel-quid chewing with or without tobacco is a major risk factor for oral potentially malignant disorders in Sri Lanka: a case-control study. Oral Oncol 2010;46:297-301.

35. Sawair FA, Al-Mutwakel A, Al-Eryani K, Al-Surhy A, Maruyama $\mathrm{S}$, Cheng J, et al. High relative frequency of oral squamous cell carcinoma in Yemen: qat and tobacco chewing as its aetiological background. Int J Environ Health Res 2007;17:185-195.

36. Ngelangel CA, Javelosa MA, Cutiongco-de la Paz EM; Philippine Cancer Genetics Study Group. Epidemiological risk factors for cancers of the lung, breast, colon-rectum \& oral cavity: a casecontrol study in the Philippines. Acta Med Philipp 2009;43:2934.

37. Loyha K, Vatanasapt P, Promthet S, Parkin DM. Risk factors for oral cancer in northeast Thailand. Asian Pac J Cancer Prev 2012; 13:5087-5090.

38. Saini R, Tang TH, Zain RB, Cheong SC, Musa KI, Saini D, et al. Significant association of high-risk human papillomavirus (HPV) but not of p53 polymorphisms with oral squamous cell carcinomas in Malaysia. J Cancer Res Clin Oncol 2011;137:311-320.

39. Karki YB, Pant KD, Pande BR. A study on the economics of tobacco in Nepal; 2003 [cited 2017 Mar 25]. Available from: https:// escholarship.org/uc/item/7zj8q2dj\#page-1.

40. Güneri P, Cankaya H, Yavuzer A, Güneri EA, Erişen L, Ozkul D, et al. Primary oral cancer in a Turkish population sample: association with sociodemographic features, smoking, alcohol, diet and dentition. Oral Oncol 2005;41:1005-1012.

41. Kaduri P, Kitua H, Mbatia J, Kitua AY, Mbwambo J. Smokeless tobacco use among adolescents in Ilala Municipality, Tanzania. Tanzan J Health Res 2008;10:28-33.

42. Nair J, Ohshima H, Friesen M, Croisy A, Bhide SV, Bartsch H. Tobacco-specific and betel nut-specific N-nitroso compounds: occurrence in saliva and urine of betel quid chewers and formation in vitro by nitrosation of betel quid. Carcinogenesis 1985;6: 295-303.

43. Nair UJ, Floyd RA, Nair J, Bussachini V, Friesen M, Bartsch H. Formation of reactive oxygen species and of 8-hydroxydeoxyguanosine in DNA in vitro with betel quid ingredients. Chem Biol Interact 1987;63:157-169.

44. Reichart PA, Schmidtberg W, Scheifele C. Betel chewer's mucosa in elderly Cambodian women. J Oral Pathol Med 1996;25:367370.

45. Ikeda N, Handa Y, Khim SP, Durward C, Axéll T, Mizuno T, et al. Prevalence study of oral mucosal lesions in a selected Cambodian population. Community Dent Oral Epidemiol 1995;23:49-54.

46. Ysaol J, Chilton JI, Callaghan P. A survey of betel nut chewing in Palau. Isla 1996;4:244-255.

47. Warnakulasuriya S. Areca nut use following migration and its consequences. Addict Biol 2002;7:127-132.

48. Bedi R, Gilthorpe MS. The prevalence of betel-quid and tobacco chewing among the Bangladeshi community resident in a United 
Kingdom area of multiple deprivation. Prim Dent Care 1995;2: 39-42.

49. Ahmed S, Rahman A, Hull S. Use of betel quid and cigarettes among Bangladeshi patients in an inner-city practice: prevalence and knowledge of health effects. Br J Gen Pract 1997;47:431-434.

50. Babu S, Sesikeran B, Bhat RV. Oral fibrosis among teenagers chewing tobacco, areca nut, and pan masala. Lancet 1996;348:692.

51. Jyoti S, Khan S, Afzal M, Naz F, Siddique YH. Evaluation of micronucleus frequency by acridine orange fluorescent staining in bucccal epithelial cells of oral submucosus fibrosis (OSMF) patients. Egypt J Med Human Genet 2013;14:189-193.

52. Morton JF. Further associations of plant tannins and human cancer. Q J Crude Drug Res 1972;12:1829-1841.

53. Stich HF, Stich W. Chromosome-damaging activity of saliva of betel nut and tobacco chewers. Cancer Lett 1982;15:193-202.

54. Giri AK, Banerjee TS, Talukder G, Sharma A. Induction of sister chromatid exchange and dominant lethal mutation by 'Katha' (catechu) in male mice. Cancer Lett 1988;38:357-364.

55. Dunham LJ, Sheets RH, Morton JF. Proliferative lesions in cheek pouch and esophagus of hamsters treated with plants from Curacao, Netherland Antilles. J Natl Cancer Inst 1974;53:1259-1269.

56. Bhide SV, Gothoskar SV, Shivapurkar NM. Arecoline tumorigenicity in Swiss strain mice on normal and vitamin B deficient diet. J Cancer Res Clin Oncol 1984;107:169-171.

57. Rojas E, Valverde M, Sordo M, Ostrosky-Wegman P. DNA damage in exfoliated buccal cells of smokers assessed by the single cell gel electrophoresis assay. Mutat Res 1996;370:115-120.

58. Speit G, Witton-Davies T, Heepchantree W, Trenz K, Hoffmann $\mathrm{H}$. Investigations on the effect of cigarette smoking in the comet assay. Mutat Res 2003;542:33-42.

59. Katyal S, McKinnon PJ. DNA strand breaks, neurodegeneration and aging in the brain. Mech Ageing Dev 2008;129:483-491.

60. Jyoti S, Khan S, Afzal M, Siddique YH. Micronucleus investigation in human buccal epithelial cells of gutkha users. Adv Biomed Res 2012;1:35.

61. Jeng JH, Chang MC, Hahn LJ. Role of areca nut in betel quid-associated chemical carcinogenesis: current awareness and future perspectives. Oral Oncol 2001;37:477-492.

62. Chiu CJ, Chang ML, Chiang CP, Hahn LJ, Hsieh LL, Chen CJ. Interaction of collagen-related genes and susceptibility to betel quidinduced oral submucous fibrosis. Cancer Epidemiol Biomarkers Prev 2002;11:646-653.

63. Kandasamy M, Anisa N, Rahman A, Rajan MA, Prakash A, Lal J. Etiopathogenesis of oral submucous fibrosis: review of literature. J Adv Med Dent Sci Res 2015;3:53-58.

64. Nair J, Nair UJ, Ohshima H, Bhide SV, Bartsch H. Endogenous nitrosation in the oral cavity of chewers while chewing betel quid with or without tobacco. IARC Sci Publ 1987:465-469.

65. Nair U, Bartsch H, Nair J. Alert for an epidemic of oral cancer due to use of the betel quid substitutes gutkha and pan masala: a review of agents and causative mechanisms. Mutagenesis 2004;19: 251-262.

66. Jyoti S, Afzal M, Siddique YH. Genotoxic effects of pan masala and gutkha: a review. World J Zool 2011;6:301-306.

67. Fareed M, Afzal M, Siddique YH. Micronucleus investigation in buccal mucosal cells among pan masala/gutkha chewers and its relevance for oral cancer. Biol Med 2011;3:8-15.

68. Jadhav K, Gupta N, Ahmed MB. Micronuclei: an essential biomarker in oral exfoliated cells for grading of oral squamous cell carcinoma. J Cytol 2011;28:7-12.

69. Sudha S, Mythili B, Balachandar V. Mixture of betel leaf, areca nut and tobacco chewing is a risk factor for cytogenetic damage in construction workers from south India. Braz J Oral Sci 2009;8: 145-148.

70. Patel BP, Trivedi PJ, Brahmbhatt MM, Shukla SN, Shah PM, Bakshi SR. Micronuclei and chromosomal aberrations in healthy tobacco chewers and controls: a study from Gujarat, India. Arch Oncol 2009;17:7-10.

71. Jaju RJ, Patel RK, Bakshi SR, Trivedi AH, Dave BJ, Adhvaryu SG. Chromosome damaging effects of pan masala. Cancer Lett 1992; 65:221-226.

72. Gandhi G, Kaur R, Sharma S. Chewing pan masala and/or betel quid-fashionable attributes and/or cancer menaces. J Hum Ecol 2005; 17:161-166.

73. Nair UJ, Obe G, Friesen M, Goldberg MT, Bartsch H. Role of lime in the generation of reactive oxygen species from betel-quid ingredients. Environ Health Perspect 1992;98:203-205.

74. Sirsat SM, Kandarkar SV. Histological changes in the oral mucosa of the wistar rat treated with commercial lime (calcium hydroxide)-an optical and submicroscopic study. Br J Cancer 1968;22:303315.

75. Shirname LP, Menon MM, Nair J, Bhide SV. Correlation of mutagenicity and tumorigenicity of betel quid and its ingredients. Nutr Cancer 1983;5:87-91.

76. Sundqvist K, Liu Y, Nair J, Bartsch H, Arvidson K, Grafström RC. Cytotoxic and genotoxic effects of areca nut-related compounds in cultured human buccal epithelial cells. Cancer Res 1989;49:52945298.

77. Adhvaryu SG, Dave BJ, Trivedi AH. An in vitro assessment of the genotoxic potential of pan masalas. Indian J Med Res 1989;90:131134.

78. Niphadkar MP, Bagwe AN, Bhisey RA. Mutagenic potential of Indian tobacco products. Mutagenesis 1996;11:151-154.

79. Nagabhushan M, Maru GB, Amonkar AJ, Nair UJ, Santhanam U, Ammigan N, et al. Catechin as an antimutagen: its mode of action. J Cancer Res Clin Oncol 1988;114:177-182.

80. Panigrahi GB, Rao AR. Study of the genotoxicity of the total aqueous extract of betel nut and its tannin. Carcinogenesis 1986;7:3739.

81. Mukherjee A, Chakrabarti J, Chakrabarti A, Banerjee T, Sarma A. Effect of 'pan masala' on the germ cells of male mice. Cancer Lett 1991;58:161-165.

82. Dave BJ, Trivedi AH, Adhvaryu SG. Cytogenetic studies reveal increased genomic damage among 'pan masala' consumers. $\mathrm{Mu}-$ tagenesis 1991;6:159-163.

83. Bagchi M, Balmoori J, Bagchi D, Stohs SJ, Chakrabarti J, Das DK. 
Role of reactive oxygen species in the development of cytotoxicity with various forms of chewing tobacco and pan masala. Toxicology 2002;179:247-255.

84. Yadav JS, Chadha P. Genotoxic studies in pan masala chewers: a high cancer risk group. Int J Hum Genet 2002;2:107-112.

85. Chadda R, Sengupta S. Tobacco use by Indian adolescents. Tob Induc Dis 2002;1:111-119.

86. Kumar S, Nigam SK, Shaikh SA, Saiyed HN. Effect of pan masala on sperm morphology of a mouse. Bull Environ Contam Toxicol 2003;70:1184-1188.

87. Singh R, Kour H, Jindal SK, Aggarwal AN, Gupta D, Khan GQ, et al. Global youth tobacco survey: a report from Jammu and Kashmir. JK Sci J Med Educ Res 2008;10:65-69.

88. Siddique YH, Ara G, Beg T, Afzal M. Micronucleus investigation in oral mucosal cells of gutkha/pan masala chewers. Indian Biol 2008;40:1-5.

89. Sarma AB, Chakrabarti J, Chakrabarti A, Banerjee TS, Roy D, Mukherjee D, et al. Evaluation of pan masala for toxic effects on liver and other organs. Food Chem Toxicol 1992;30:161-163.

90. Wu IC, Chen PH, Wang CJ, Wu DC, Tsai SM, Chao MR, et al. Quantification of blood betel quid alkaloids and urinary 8-hydroxydeoxyguanosine in humans and their association with betel chewing habits. J Anal Toxicol 2010;34:325-331.

91. Lin CY, Pan TS, Ting CC, Liang SS, Huang SH, Liu HY, et al. Cytochrome p450 metabolism of betel quid-derived compounds: implications for the development of prevention strategies for oral and pharyngeal cancers. Scientific World Journal 2013;2013:618032.

92. Ramchandani AG, D’Souza AV, Borges AM, Bhisey RA. Evaluation of carcinogenic/co-carcinogenic activity of a common chewing product, pan masala, in mouse skin, stomach and esophagus.
Int J Cancer 1998;75:225-232.

93. Nigam SK, Kumar A, Sheikh S, Saiyed HN. Toxicological evaluation of pan masala in pure inbred Swiss mice: a preliminary report on long-term exposure study. Curr Sci 2001;80:1306-1309.

94. Stich HF, Anders F. The involvement of reactive oxygen species in oral cancers of betel quid/tobacco chewers. Mutat Res 1989; 214:47-61.

95. Javed F, Näsström K, Benchimol D, Altamash M, Klinge B, Engström PE. Comparison of periodontal and socioeconomic status between subjects with type 2 diabetes mellitus and non-diabetic controls. J Periodontol 2007;78:2112-2119.

96. Mavropoulos A, Aars H, Brodin P. The acute effects of smokeless tobacco (snuff) on gingival blood flow in man. J Periodontal Res 2001;36:221-226.

97. Avasn Maruthit Y, Rao RS, Palivela H, Thakre S. Impact of gutkha chewing \& smoking on microbial environment of oral cavity: a case study on slum dwellers of selected areas in Visakhapatnam. J Environ Sci Eng 2004;46:268-273.

98. Tseng YH, Chang KW, Liu CJ, Lin CY, Yang SC, Lin SC. Areca nut extract represses migration and differentiation while activating matrix metalloproteinase- 9 of normal gingival epithelial cells. J Periodontal Res 2008;43:490-499.

99. Hazare VK, Goel RR, Gupta PC. Oral submucous fibrosis, areca nut and pan masala use: a case-control study. Natl Med J India 1998;11:299.

100. Gupta PC, Mehta FS, Daftary DK, Pindborg JJ, Bhonsle RB, Jalnawalla $\mathrm{PN}$, et al. Incidence rates of oral cancer and natural history of oral precancerous lesions in a 10-year follow-up study of Indian villagers. Community Dent Oral Epidemiol 1980;8:283-333. 